\section{Research Square}

Preprints are preliminary reports that have not undergone peer review.

They should not be considered conclusive, used to inform clinical practice, or referenced by the media as validated information.

\title{
Impact of Operational Conditions on Methane Yield and Microbial Community Composition during Biological Methanation in a Hybrid Reactor System
}

Radziah Wahid

Norwegian University of Life Sciences

Svein Jarle Horn ( $\nabla$ svein.hom@nmbu.no)

Norwegian University of Life Sciences https://orcid.org/0000-0002-1590-9001

\section{Research Article}

Keywords: Biological methanation, in-situ, hybrid, hydrogenotrophic methanogens, $\mathrm{CH} 4$ yield.

Posted Date: June 2nd, 2021

DOI: https://doi.org/10.21203/rs.3.rs-567358/v1

License: () (7) This work is licensed under a Creative Commons Attribution 4.0 International License. Read Full License

Version of Record: A version of this preprint was published at Biotechnology for Biofuels on August 21st, 2021. See the published version at https://doi.org/10.1186/s13068-021-02019-4. 


\section{Abstract}

Background: Biogas can be upgraded to methane biologically by adding hydrogen to biogas reactors. The process is called biological methanation (BM) and can be done in-situ in a regular biogas reactor or the biogas can be transferred to a separate ex-situ upgrading reactor. The hybrid BM concept, a combination of in-situ and ex-situ BM, has received little attention, and only a few studies have been reported. The hybrid BM has the advantage of resolving the issue of $\mathrm{pH}$ increment during in-situ $\mathrm{BM}$, while the size of the ex-situ BM reactor could be reduced.

Results: In this study, the efficiency of in-situ and hybrid biological methanation (BM) for upgrading raw biogas was investigated. The hybrid BM system achieved a $\mathrm{CH}_{4}$ yield of $257 \mathrm{~mL} \mathrm{gvs}^{-1}$ when degrading a feedstock blend of manure and cheese waste. This represented an increase in methane yield of $76 \%$ when compared to the control reactor with no $\mathrm{H}_{2}$ addition. A 2:1 $\mathrm{H}_{2}: \mathrm{CO}_{2}$ ratio resulted in stable reactor performance, while a 4:1 ratio resulted in a high accumulation of volatile fatty acids. $\mathrm{H}_{2}$ consumption rate was improved when a low manure-cheese waste ratio (90\%:10\%) was applied. Furthermore, feeding less frequently (every 48 hours) resulted in a higher $\mathrm{CH}_{4}$ production from $\mathrm{CO}_{2}$ and $\mathrm{H}_{2}$. Methanothermobacter was found to dominate the archaeal community in the in-situ BM reactor, and its relative abundance increased over the experimental time. Methanosarcina abundance was negatively affected by $\mathrm{H}_{2}$ addition and was nearly non-existent at the end of the experiment.

Conclusions: Our results show that hybrid BM outperforms in-situ BM in terms of total $\mathrm{CH}_{4}$ production and content of $\mathrm{CH}_{4}$ in the biogas. The application of hybrid $\mathrm{BM}$ increased $\mathrm{CH}_{4}$ yield up to $42 \%$. Furthermore, addition of $\mathrm{H}_{2}$ at 2:1 $\mathrm{H}_{2}: \mathrm{CO}_{2}$ ratio in in-situ $\mathrm{BM}$ resulted in stable reactor operation.

\section{Background}

Renewable electricity from photovoltaics and wind turbines could play a significant role in the future European electricity system [1]. However, wind and solar are intermittent energy sources, necessitating long-term and large-scale storage in order to store renewable electricity during excess and supply electricity during shortage [2]. One solution is to store electricity in batteries, but it has its own disadvantages, including high cost of manufacture, low storage capacity and use of rare minerals [3]. Another storage alternative is to use excess electricity from wind or solar energy to generate $\mathrm{H}_{2}$ via water electrolysis [4]. However, the use of $\mathrm{H}_{2}$ as a renewable energy carrier presents significant challenges that have not yet been addressed, linked to its low density requiring a high storage capacity infrastructure, while the direct use of $\mathrm{H}_{2}$ as transport fuel is still under development $[5,6]$. However, $\mathrm{H}_{2}$ may be combined with $\mathrm{CO}_{2}$ produced in existing biogas plants and converted to $\mathrm{CH}_{4}$, for which large scale infrastructure and applications are in place [4]. This concept of converting electrical into chemical energy is known as Power-to-Methane (PtM) [7].

PtM can be achieved in two ways, either by thermochemical methanation (TM) or BM [1]. Both methods are based on the Sabatier reaction (Eq. 1), in which four moles of $\mathrm{H}_{2}$ react with one mole of $\mathrm{CO}_{2}$ to produce one mole of $\mathrm{CH}_{4}$ and two moles of $\mathrm{H}_{2} \mathrm{O}$ [8]:

$4 \mathrm{H}_{2}+\mathrm{CO}_{2} \rightarrow \mathrm{CH}_{4}+2 \mathrm{H}_{2} \mathrm{O} \Delta \mathrm{G}^{0 囚}=-130 \mathrm{~kJ} \mathrm{~mol}^{-1}($ Eq. 1)

Metal catalysts such as $\mathrm{Ni}$ and $\mathrm{Al}_{2} \mathrm{O}_{3}$ are used in $\mathrm{TM}$, which operates at high temperatures (between 200 and $500^{\circ} \mathrm{C}$ ) and pressures (up to 100 bar). The metal catalyst is sensitive to contaminants such as hydrogen sulphide $\left(\mathrm{H}_{2} \mathrm{~S}\right)$, so high purity of the reactant gases is required [2]. BM, on the other hand, uses a biological catalyst (methanogenic archaea) and operates at mild temperatures ( 35 to $65^{\circ} \mathrm{C}$ ) and pressures ( $<15$ bar). In addition, as opposed to TM, the process tolerates impurities such as $\mathrm{H}_{2} \mathrm{~S}$ [2]. At present, $\mathrm{BM}$ is gaining more attention as a result of its advantages, and a growing number of studies have been dedicated to it [9-11]. Previous research has reported three types of BM concepts: in-situ [11, 12], ex-situ [13, 14], and hybrid [15].

In-situ BM is attractive since biogas is upgraded directly in the biogas reactor without incurring additional costs for a secondary reactor. However, some technical challenges have been reported in previous studies $[11,12]$ such as increased pH $(>8.5)$ due to bicarbonate removal to $\mathrm{CH}_{4}$ and high $\mathrm{H}_{2}$ partial pressure (exogenous $\mathrm{H}_{2}$ ), which inhibits the activity of specific bacteria and methanogens. Furthermore, the low $\mathrm{H}_{2}$ gas-liquid mass transfer rate limits methanogen uptake of $\mathrm{H}_{2}$ for $\mathrm{CO}_{2}$ to $\mathrm{CH}_{4}$ conversion, which is a key challenge for both in-situ and ex-situ $\mathrm{BM}$ [16]. Ex-situ $\mathrm{BM}$ involves the injection of $\mathrm{CO}_{2}$ from biogas (or other sources) and $\mathrm{H}_{2}$ into a separate reactor containing hydrogenotrophic methanogens (pure or enriched culture) for $\mathrm{CH}_{4}$ conversion [6]. The hybrid BM concept (combination of in-situ and ex-situ), on the other hand, has received little attention, and only a few studies have been conducted. The hybrid $\mathrm{BM}$ has the advantage of addressing the issue of $\mathrm{pH}$ increment during in-situ $\mathrm{BM}$, while smaller reactor size could be the option for ex-situ BM [6]. Corbellini et al., [15] used a two-stage thermophilic reactor to investigate the performance of hybrid BM and obtained final $\mathrm{CH}_{4}$ concentrations of more than $95 \%$ in some experiments. The hybrid concept was also proposed by Voelklein et al., [17] for full scale application as an alternative to conventional upgrading systems.

The goal of this study was to assess the performance of a hybrid BM system in terms of substrate conversion efficiency and biogas quality using a $10 \mathrm{~L}$ continuous-stirred tank reactor (CSTR) (in-situ) and a $2 \mathrm{~L}$ reactor with packing materials (ex-situ). A similar CSTR reactor without $\mathrm{H}_{2}$ addition was used as a control. Furthermore, the performance of in-situ and hybrid systems was compared in order to evaluate the capability of hybrid BM in resolving technical challenges associated with in-situ, such as $\mathrm{pH}$ increment and low $\mathrm{H}_{2}$ gas-liquid mass-transfer rate. This work also investigated parameters (e.g. $\mathrm{H}_{2}$ : $\mathrm{CO}_{2}$ ratio, stirring speed, and feeding frequency ) that affect the efficiency of in-situ BM and the composition and dynamics of the microbial populations. Parameters such as $\mathrm{pH}$, total ammonium nitrogen (TAN), volatile fatty acids (VFA), and methane yield and content were closely monitored during the experiment.

\section{Results And Discussion}

\section{Process performance and biogas upgrading of in-situ BM}


The characteristics of the inoculum and the applied substrates are given in Table 1. Operating parameters and performance data for the $10 \mathrm{~L}$ control and upgrading reactors (CR, UR) under steady-state conditions are summarized in Table 2 and 3, respectively. The experiment was conducted for 172 days and divided into six phases. Figures 2 and 3 illustrate the changes in methane yield, $\mathrm{pH}$, and VFAs over the experimental period for upgrading and control reactors.

\section{Phase I: Initial phase - without $\mathrm{H}_{2}$ addition}

In this phase, the two reactors were operated identically and showed very similar performance in terms of biogas production (241-245 $\left.\mathrm{mL} \mathrm{g}^{-1} \mathrm{vs}\right)$ and $\mathrm{CH}_{4}$ yield (144-145 mL g ${ }^{-1}$ vs) (Table 3). The average $\mathrm{CH}_{4}$ content of the reactors (58 to 59\%) and the $\mathrm{pH}$ (7.9) were also similar. The total VFA content was around 18 $\mathrm{mM}$, with acetic acid (AA) accounting for more than $60 \%$ of the total VFAs. The ratio of propionic acid (PA) to AA of both reactors was below 1.4 , indicating a stable AD process according to [18]. The TAN concentration was around $2.5 \mathrm{~g} \mathrm{~L}^{-1}$. The values align well with those obtained by [19], who observed that a TAN value of $2.5 \mathrm{~g} \mathrm{~L}^{-1}(\mathrm{pH} 7.9)$ resulted in stable biogas production during thermophilic $\left(55^{\circ} \mathrm{C}\right)$ anaerobic digestion of cow manure.

\section{Phase Il: Initial $\mathrm{H}_{2}$ phase}

$\mathrm{H}_{2}$ was added in UR from day 64 at a flow rate of $3 \mathrm{~mL} \mathrm{~min}{ }^{-1}$, corresponding to a $\mathrm{H}_{2}: \mathrm{CO}_{2}$ ratio of $2: 1$. As shown in Figure $2, \mathrm{CH}_{4}$ yield increased immediately after $\mathrm{H}_{2}$ addition and stabilized from day 70 . The average $\mathrm{CH}_{4}$ yield of UR was $185 \mathrm{~mL} \mathrm{~g}^{-1}$ vs, which was approximately $27 \%$ higher than the average $\mathrm{CH}_{4}$ yield of CR (Table 3). A similar observation was reported by Treu et al., [20] where $\mathrm{H}_{2}$ addition into a CSTR at a 2:1 ratio resulted $13 \%$ increase in $\mathrm{CH}_{4}$ yield. The $\mathrm{pH}$ of UR increased from 7.94 to 8.10 , while the $\mathrm{pH}$ of $\mathrm{CR}$ remained the same as in phase 1 . $\mathrm{BM}$ resulted in a rise in $\mathrm{pH}$ due to the removal of $\mathrm{CO}_{2}$ from the liquid phase. Bicarbonate ions $\left(\mathrm{HCO}_{3}{ }^{-}\right)$are produced during the $\mathrm{AD}$ process when $\mathrm{CO}_{2}$ reacts with $\mathrm{OH}$ in the liquid phase, contributing to the buffering capacity of the reactor. Addition of $\mathrm{H}_{2}$ to the system resulted in $\mathrm{CO}_{2}$ consumption and thus loss of buffering capacity [14]. Similar findings have been reported in previous studies $[11,20,21]$. Total VFA levels in UR rose to more than double the amount in phase I. In contrast to our study, Treu et al., [20] reported relatively low and stable VFA levels after $\mathrm{H}_{2}$ addition.

In $\mathrm{CR}$, the average AA concentration was $21 \mathrm{mM}$, while in UR, it was $36 \mathrm{mM}$. PA levels were slightly higher in both reactors than in phase 1. TAN concentrations were also elevated, with $2.57 \mathrm{~g} \mathrm{~L}^{-1}$ for $\mathrm{CR}$ and $2.77 \mathrm{~g} \mathrm{~L}^{-1}$ for UR. The $\mathrm{H}_{2}$ consumption rate of UR was calculated to be $25 \%$, corresponding to a $\mathrm{CH}_{4}$ production rate of $0.04 \mathrm{~mL} \mathrm{~L}^{-1} \mathrm{~d}^{-1}$.

\section{Phase III: Increased stirring speed}

In phase III, the stirring speed of both reactors was increased from 80 to $140 \mathrm{rpm}$ (day 79) in an attempt to improve the transfer of $\mathrm{H}_{2}$ to the liquid phase in UR. As shown in Figure 2, the $\mathrm{CH}_{4}$ yield from UR decreased significantly as the stirring speed increased. The $\mathrm{CH}_{4}$ yield of UR was reduced from 185 (day 78 ) to 126 $\mathrm{mL} \mathrm{g}^{-1}$ vs (day 85) for UR. The decrease in $\mathrm{CH}_{4}$ yield of UR was corroborated by the accumulation of acetate (67 mM on average), which was nearly double of what was measured in phase II (Figure $3 b$ ). Besides, the propionate concentration was slightly increased from 9 to $13 \mathrm{mM}$. These observations could indicate that parts of the microbial community were negatively affected by the higher share forces at $140 \mathrm{rpm}$.

Regardless of the fact that the total $\mathrm{CH}_{4}$ yield decreased as the stirring speed increased, the $\mathrm{H}_{2}$ consumption rate in UR increased from $25 \%$ to $46 \%$. This observation was in agreement with our previous study [22]. The rate of $\mathrm{CH}_{4}$ production from $\mathrm{H}_{2}$ and $\mathrm{CO}_{2}$ conversion was increased from 0.04 to $0.08 \mathrm{~mL} \mathrm{~L}^{-1} \mathrm{~d}$ 1. For the $\mathrm{CR}$, the $\mathrm{CH}_{4}$ yield was reduced from 143 to $131 \mathrm{~mL} \mathrm{~g}^{-1}$ vs. Ghanimeh et al., [23] observed a decrease in $\mathrm{CH}_{4}$ yield when stirring speed was increased from 80 to $120 \mathrm{rpm}$. No AA accumulation was observed in the CR, whereas the PA level was slightly higher than in phase II (12 mM) (Figure $3 a$ and Table 3). The $\mathrm{pH}$ in both reactors was higher than in phase II, with $\mathrm{pH}$ of 8.15 and 8.28 for $\mathrm{CR}$ and UR, respectively. The elevated $\mathrm{pH}$ in UR can be attributed to greater $\mathrm{CO}_{2}$ consumption in the liquid as a result of the increased $\mathrm{H}_{2}$ gas-liquid mass transfer rate at higher stirring speeds and thus higher BM activity [1].

\section{Phase IV: Change of feedstock blend ratio}

On day 86 , the stirring speed was again reduced to $80 \mathrm{rpm}$ (return to Phase II conditions), and the $\mathrm{CH}_{4}$ yield rose significantly until it reached a plateau from day 90 (Figure 2). From day 92 the $\mathrm{CW}$ fraction was increased from $10 \%$ to $20 \%$ on day 93 (Phase IV), resulting in an OLR of $0.78 \mathrm{gvs}_{\mathrm{Vs}} \mathrm{L}^{-1} \mathrm{~d}^{-1}$. The $\mathrm{CH}_{4}$ yield increased in both reactors, with maximum values being $195 \mathrm{~mL} \mathrm{~g}^{-1} \mathrm{vs}$ (CR) and $276 \mathrm{~mL} \mathrm{~g}^{-1}$ vs (UR) (Figure 2). After day 102 , however, the $\mathrm{CH}_{4}$ yield gradually decreased until it reached a stable period around day 111. During the stable period, the average $\mathrm{CH}_{4}$ yields of $\mathrm{CR}$ and $\mathrm{UR}$ were $142 \mathrm{~mL} \mathrm{\textrm {g } ^ { - 1 }} \mathrm{vs}$ and $204 \mathrm{~mL} \mathrm{~g}^{-1} \mathrm{vs}$ respectively (Table 3). The average $\mathrm{CH}_{4}$ yield of $\mathrm{CR}$ measured in this study was lower than that measured by Comino et al., [24] (similar feedstock blend, 80\% CM:20\% whey), despite the fact that both studies had comparable $\mathrm{CH}_{4}$ content (53\%). Longer HRT (41 days) and higher OLR (3.33 gvs $\mathrm{L}^{-1} \mathrm{~d}^{-1}$ ) were used by Comino et al., which may explain the difference in performance. The average $\mathrm{CH}_{4}$ content of UR was $39 \%$. The $\mathrm{H}_{2}$ consumption rate was around $17 \%$, which was $31 \%$ lower than the consumption rate when CW fraction was set at $10 \%$. The total VFA content of CR was slightly higher towards the end of phase IV (Figure 3a), while the total VFA content of UR was relatively stable (Figure 3b). The $\mathrm{pH}$ of both reactors was lower than in phase III, with an average pH of 7.91 for CR and 8.11 for UR. Increased CW ratio to $20 \%$ resulted in higher TAN values (both reactors) compared to phase II, suggesting more thorough CW degradation as TAN is a product of protein degradation.

\section{Phase V: Feeding frequency}

In phase $\mathrm{V}$, the $\mathrm{CW}$ fraction was reduced to $10 \%$ and the feeding frequency was changed to once every 48 hours (instead of once per 24 hours). In term of $\mathrm{CH}_{4}$ yield for $\mathrm{CR}$, no changes were observed, while $\mathrm{CH}_{4}$ yield for UR was gradually reduced until a stable period was achieved (day 134$)$. The average $\mathrm{CH}_{4}$ yield for 
CR was $139 \mathrm{~mL} \mathrm{~g}^{-1}$ vs and $194 \mathrm{~mL} \mathrm{~g}^{-1}$ vs for UR. The $\mathrm{CH}_{4}$ yield of UR in phase IV was slightly higher than in phase II (feeding every 24 hours). The $\mathrm{H}_{2}$ consumption rate was higher than phase II ( $24 \mathrm{~h}$ feeding) when the reactor was fed every 48 hours $\left(25 \%\right.$ vs $32 \%$ ). The increased $\mathrm{CH}_{4}$ yield and $\mathrm{H}_{2}$ consumption rate in UR could be attributed to enrichment of hydrogenotrophic methanogens in less frequent feeding. According to Piao et al., [25], reducing feeding frequency tended to increase the abundance of $\mathrm{H}_{2}$-utilizing methanogens. In the Piao study, the abundance of hydrogenotrophic methanogens increased from $45 \%$ to $53 \%$ when feeding frequency was reduced from every 24 hours to every 48 hours. The average total VFA content for CR and UR were 26 and $50 \mathrm{mM}$, respectively. The $\mathrm{pH}$ of both reactors was slightly lower than in phase II.

\section{Phase Vl: Increased $\mathrm{H}_{2}: \mathrm{CO}_{2}$ ratio}

Substrate feeding was changed to once daily starting on day 141 , and the $\mathrm{H}_{2}$ flow rate was increased to $6 \mathrm{~mL} \mathrm{~min}^{-1}$, equivalent to a $4: 1 \mathrm{H}_{2}: \mathrm{CO}_{2}$ ratio $(\mathrm{Phase}$ $\mathrm{VI}$ ). The increased $\mathrm{H}_{2}: \mathrm{CO}_{2}$ ratio initially boosted $\mathrm{CH}_{4}$ yield in UR with a maximum at day 151 . However, the yield fell after day 163 . The average $\mathrm{CH}_{4}$ yield in this period was $165 \mathrm{~mL} \mathrm{~g}^{-1} \mathrm{vs}$, about $11 \%$ lower than the value in phase II $\left(\mathrm{H}_{2}: \mathrm{CO}_{2}\right.$ ratio $\left.=2: 1\right)$. Despite the lower $\mathrm{CH}_{4}$ yield, the $\mathrm{H}_{2}$ consumption rate was doubled (54\%) compared to phase II (25\%) due to the increased $\mathrm{H}_{2}: \mathrm{CO}_{2}$ ratio, which probably stimulated $\mathrm{H}_{2}$-consuming anaerobic microbes.

AA accumulated toward the end of the phase, reaching a maximum concentration of $84.5 \mathrm{mM}$. The increase in AA levels may be explained by the inhibition of acetoclastic methanogens (e.g. Methanosarcina) caused by high $\mathrm{H}_{2}$ partial pressure [26] or by the enrichment of particular microbial pathways such as homoacetogenesis (Wood-Ljungdahl pathway) [6]. PA content was also increased from 15 to $18 \mathrm{mM}$ when the $\mathrm{H}_{2}: \mathrm{CO}_{2}$ ratio was increased. The rise in total VFA content coincided with a drop in $\mathrm{pH}$ from 8.01 to 7.91. For $\mathrm{CR}$, the $\mathrm{CH}_{4}$ yield remained consistent throughout phase $\mathrm{VI}$, with an average of $134 \mathrm{~mL} \mathrm{~g}^{-1} \mathrm{vs}$. The average total VFA concentration was $21 \mathrm{mM}$, with a pH of 7.82. AA concentration accounted for $58 \%$ of the total VFA content. The TAN concentration was $2.65 \mathrm{~g} \mathrm{~L}-1$, which was similar to the value observed in phase II (2.57 g L-1).

\section{In-situ vs. hybrid configurations}

A hybrid configuration was tested at the end of the experiment (after day 172). An additional $2 \mathrm{~L}$ reactor filled with packing materials was used as an ex-situ biogas upgrading reactor (HR) for the biogas from UR (Figure 1b). Initially, the operating parameters of UR were adjusted to the same as in phase II with a $\mathrm{H}_{2}: \mathrm{CO}_{2}$ ratio of $2: 1$.

When the hybrid setup was used instead of an in-situ (phase II), 39\% extra $\mathrm{CH}_{4}$ was obtained (Figure 4). The average $\mathrm{CH}_{4}$ yield rose from 185 to $257 \mathrm{~mL}{ }^{-1}$ vs. Furthermore, the $\mathrm{H}_{2}$ consumption rate increased by twofold compared to in-situ (phase II), and the average $\mathrm{CH}_{4}$ content increased from $40 \%$ to $63 \%$ (Tables 3 \& 4). The $\mathrm{CH}_{4}$ content without considering $\mathrm{H}_{2}$ from hybrid system was around $80 \%$. When compared to the control reactor (Figure 4), the hybrid configuration resulted in a $76 \%$ higher $\mathrm{CH}_{4}$ yield, while in-situ configuration resulted in $27 \%$ more $\mathrm{CH}_{4}$ (Figure 4). HR had an average pH of 8.07 and an AA concentration of approximately $4.12 \mathrm{mM}$. The TAN concentration of HR was around $1.09 \mathrm{~g} \mathrm{~L}-1$.

The $\mathrm{H}_{2}: \mathrm{CO}_{2}$ ratio was increased to 4:1 after a stable condition was observed. The average $\mathrm{CH}_{4}$ yield fell from $257 \mathrm{~mL} \mathrm{~g}{ }^{-1} \mathrm{vs}$ to $234 \mathrm{~mL} \mathrm{~g}{ }^{-1} \mathrm{vs}$ (approximately $9 \%$ less $\left.\mathrm{CH}_{4}\right)$. The average $\mathrm{CH}_{4}$ content was reduced from 63 to $51 \%$. Nonetheless, the $\mathrm{H}_{2}$ consumption rate $(62 \%)$ was slightly higher than at the $2: 1 \mathrm{H}_{2}$ : $\mathrm{CO}_{2}$ ratio $(60 \%)$, indicating that acetate-oxidizing bacteria had the capacity to consume more $\mathrm{H}_{2}$ to produce acetate, as observed in phase VI. Compared to in-situ configuration (phase $\mathrm{VI}$ ), about $42 \%$ extra $\mathrm{CH}_{4}$ was measured and approximately $75 \%$ more $\mathrm{CH}_{4}$ was produced when compared to control (Figure 4 ). The concentrations of $\mathrm{AA}$ and TAN were equivalent to those found at a $2: 1 \mathrm{H}_{2}: \mathrm{CO}_{2}$ ratio.

Compared to Corbellini et al., [15] our study resulted in lower upgraded $\mathrm{CH}_{4}$ content of in-situ BM. This may be attributed to differences in reactor working volume, as a larger working volume (6L) was used in the present study compared to $3 \mathrm{~L}$ in [15]. Our findings were more comparable to those of [17], who used a $9 \mathrm{~L}$ working volume for in-situ testing. Furthermore, when a $4: 1 \mathrm{H}_{2}: \mathrm{CO}_{2}$ ratio was added to UR in our study, $\mathrm{AA}$ accumulation $\left(>4 \mathrm{~g} \mathrm{~L} \mathrm{~L}^{-1}\right)$ was observed, leading to a decrease in $\mathrm{pH}$, while VFA level observed in [15] was maintained at $2 \mathrm{~g} \mathrm{~L}^{-1}$.

To prevent process instability in in-situ $\mathrm{BM}$ reactor, we propose that the amount of $\mathrm{H}_{2}$ added to the in-situ reactor should be kept at a relatively low $\mathrm{H}_{2}: \mathrm{CO}_{2}$ ratio (e.g. 2:1). This will minimize the increase in $\mathrm{pH}$ caused by bicarbonate removal as well as the possible inhibition of some anaerobic bacteria that are sensitive to high $\mathrm{H}_{2}$ partial pressure. Our study discovered residual $\mathrm{H}_{2}$ in the in-situ and hybrid BM reactors, indicating that further optimization is required. A pressurized reactor may be a solution. Increased operating pressure enhances the solubility of gases and decreases bubble size. Smaller bubble size is beneficial since it maximizes the contact area between bacteria and gaseous substrates while slowing gas upflow through the reactor [1,27]. Previous research found that increasing reactor pressure during in-situ and ex-situ BM resulted in improved conversion efficiency [28,29]. A very high $\mathrm{CH}_{4}$ concentration (>98\%) in the biogas was reported when reactor pressure was set between 5 and 15 bars for a $5 \mathrm{~m}^{3}$ ex-situ CSTR [30]. Additionally, the design of the ex-situ reactor used in our study can be improved, for example, by using a long column design like trickle-bed reactor.

\section{Microbial community composition}

Microbial analysis of the reactor feed ( $80 \% \mathrm{CM}: 20 \% \mathrm{CW}$ ) showed that Firmicutes and Proteobacteria were the two dominant bacterial phyla, accounting for approximately 50 and $18 \%$ of the abundance, respectively (Figure 5a). Other phyla present in the feed included Actinobacteria ( $9 \%$ ) and Bacteriodetes (8\%). Analysis of the inoculum microbiology showed that Firmicutes was the dominating phylum (71\%), followed by Synergistetes (7\%), Actinobacteria, and Euryarchaeota (both phyla accounted 3\% abundance) (Figure 5b). Atribacteria and Thermotogae were also detected in the inoculum, but they were not found in the feed sample. 
The taxonomic classification of the microbial community revealed that Firmicutes were the most abundant phyla $\mathrm{n}$ the reactors, accounting for 57 to $72 \%$ of relative abundance depending on the time points (Figure 5c). This is in agreement with the findings of [31] where Firmicutes dominated a thermophilic biogas reactor digesting cow manure. Firmicutes engages in a variety of metabolic processes for carbohydrate and fatty acid degradation, including the WoodLjungdahl pathway (homoacetogenesis) and syntrophic acetate oxidation, which explains their abundance in the reactors [11]. Clostridia, which belong to the Firmicutes, was the most abundant class (representing more than $33 \%$ of all bacterial sequences). Other bacterial phyla, such as Synergistetes and Bacteriodetes, were present in both reactors at first, but their numbers declined over time. In terms of methanogenic population, the abundance of Euryarchaeota varied over time, between $13-33 \%$ for CR, and $18-38 \%$ for UR (Figure $5 c$ ).

Some bacteria, such as $H A W-R 60$, an Atribacteria phyla, was clearly negatively affected by $\mathrm{H}_{2}$ addition (Figure 6a). Their abundance declined over time and was nearly non-existent in phase VI.Atribacteria have been found previously in thermophilic biogas reactors and are involved in hydrolysis of polysaccharides [32]. Another hydrolytic bacterium, Halocella, behaved differently, reaching highest abundance when the $\mathrm{H}_{2}: \mathrm{CO}_{2}$ ratio was increased to $4: 1$ (phase $\mathrm{VI}$ ) (Figure 6b). Their abundance in UR increased from 6.7 (without $\mathrm{H}_{2}$ addition) to $14.6 \%$. The increase in stirring speed in phase II (day $79-85$ ) seemed to negatively affect Halocella, with decreased abundance in both CR and UR. The cellulolytic bacteria Halocella belong to the class Clostridia and is responsible for cellulose degradation and produces ethanol and $\mathrm{H}_{2}$ from lignocellulosic substrates [33]. Halocella have mainly been found in manure-based samples and their presence in thermophilic biogas reactor has been reported previously [34].

Within the domain archaea, Methanosarcina was the only detected methanogen capable of acetoclastic methanogenesis, although it can also carry out hydrogenotrophic methanogenesis [35]. Methanosarcina was clearly negatively affected by $\mathrm{H}_{2}$ addition and disappeared from UR after 108 days (Figure 6c). High $\mathrm{H}_{2}$ partial pressure has previously been shown to be detrimental to Methanosarcina [36]. Furthermore, the observed accumulation of AA in UR (Figure 3b) is in agreement with inhibition of Methanosarcina.

In contrast to Methanosarcina, the hydrogenotrophic methanogen Methanothermobacter increased in abundance over time and responded positively to $\mathrm{H}_{2}$ addition. Methanothermobacter are typical hydrogenotrophic methanogens that are commonly found in thermophilic biogas reactors [37]. As shown in Figure $6 \mathrm{~d}$, their abundance in UR got higher than the abundance in CR over time, suggesting that they were enriched as a result of $\mathrm{H}_{2}$ addition. The high abundance of Methanothermobacter found in this study is consistent with previous research that found this genus to be dominant in thermophilic biogas upgrading systems $[6,14,38]$. According to [39], Methanothermobacter expand rapidly when $\mathrm{H}_{2}$ is abundant and are adaptable to different concentrations of dissolved $\mathrm{H}_{2}$.

Syntrophaceticus abundance increased rapidly in UR when $\mathrm{H}_{2}$-supplementation was initiated but was greatly reduced after day 140 when the $48 \mathrm{~h}$ feeding regime was introduced (Figure 6e). Syntrophaceticus is a well-known syntrophic acetate-oxidizing (SAO) bacterium that was discovered in a biogas reactor that relied on the energy from acetate oxidation to produce $\mathrm{H}_{2}$ and $\mathrm{CO}_{2}$ [15,34]. SAO bacteria, which are syntrophic with hydrogenotrophic methanogens (Methanothermobacter in our case), can be inhibited by short or long-term $\mathrm{H}_{2}$ addition to their living atmosphere [20,35]. Increased $\mathrm{H}_{2}$ partial pressure can inhibit SAO from a thermodynamic perspective because syntrophic sustainability is dependent on the $\mathrm{H}_{2}$ /formate concentration, which is usually kept low by the methanogenic partners [40]. Interestingly, our study revealed that $\mathrm{H}_{2}$ addition at an $\mathrm{H}_{2}: \mathrm{CO}_{2}$ ratio of 2:1 promotes the growth of Syntrophaceticus while increasing the $\mathrm{H}_{2}: \mathrm{CO}_{2}$ ratio to $4: 1$ significantly reduces their abundance. In addition, the abundance of Syntrophaceticus of was maximum when the CW ratio was increased from 10 to $20 \%$.

Similar to Halocella, $f_{-} H y d r o g e n i s p o r a c e a e \_O T U \_28$, was also affected by the increased stirring speed, seen as reduced abundance after $64 \mathrm{~h}$ in both reactors (Figure 6f). f_Hydrogenisporaceae_OTU_28, a member of the OPB54 class, have previously been reported to be involved in the fermentation of carbohydrates to produce acetate and $\mathrm{H}_{2}[41]$.

Our findings revealed that the $\mathrm{H}_{2}: \mathrm{CO}_{2}$ ratio, stirring speed, $\mathrm{CM}: \mathrm{CW}$ ratio, and feeding frequency all had an effect on in-situ $\mathrm{BM}$, either on overall $\mathrm{CH}_{4}$ production or on $\mathrm{CH}_{4}$ production from $\mathrm{H}_{2}$ and $\mathrm{CO}_{2}$ conversion. However, it was only the $\mathrm{H}_{2}: \mathrm{CO}_{2}$ ratio and stirring speed that strongly affected the microbial community profile of the reactors.

\section{Conclusions}

The current work demonstrates the feasibility of the hybrid biogas upgrading concept and identifies some challenges that must be tackled for future process improvement. When hybrid BM was used instead of in-situ BM, it resulted in a $39 \%$ increase in $\mathrm{CH}_{4}$ yield. Furthermore, maximum $\mathrm{H}_{2}$ utilization (62\%) was observed during hybrid BM. The co-digestion of $\mathrm{CM}$ and $\mathrm{AC}$ aided in keeping the $\mathrm{pH}$ of the reactor below 8.1 during in-situ $\mathrm{BM}$. The addition of $\mathrm{H}_{2}$ at a $\mathrm{H}_{2}: \mathrm{CO}_{2}$ ratio of 2:1 resulted in stable operation of the in-situ reactor system, while at higher ratio VFAs started to accumulate resulting in pH drop. The microbial analysis revealed that Methanothermobacter, a hydrogenotrophic methanogen, dominates both the control and the $\mathrm{H}_{2}$ reactors, with a higher abundance in the $\mathrm{H}_{2}$ reactor. The main factors affecting the microbial community composition were $\mathrm{H}_{2}$ addition and stirrer speed. The findings of our study may be useful to other researchers or biogas plant operators in developing processes for enhancing BM performance and methane yields.

\section{Materials And Methods}

\section{Inoculum and substrate}

Thermophilic inoculum was obtained from two 10L CSTRs digesting cow manure (CM) collected from a cow farm in Ås, Norway. Both reactors were operated at $55^{\circ} \mathrm{C}$ and 20 days of hydraulic retention time. The same $\mathrm{CM}$ was also used as a model substrate for the present study. To limit $\mathrm{pH}$ increment during in-situ $\mathrm{BM}$, the CM was co-digested with acidic cheese obtained from the Food pilot plant at Norwegian University of Life Sciences (NMBU). The cheese was

Page 5/14 
produced only for experimental purposes [42] and discarded once the experiment was completed. The cheese waste (CW) was collected and was stored at $4^{\circ} \mathrm{C}$ until further usage. Table 1 lists the characteristics of the inoculum and substrates used in this study.

\section{In-situ BM setup}

The setup comprised of two $10 \mathrm{~L}$ CSTRs (Control reactor, CR, and in-situ upgrading reactor, UR), each with $6 \mathrm{~L}$ working volume. The temperature of both reactors was maintained at thermophilic condition $\left(55^{\circ} \mathrm{C}\right)$. Three-blade Elephant Ear impeller operated in the down-pumping mode was used for mixing at 80 rpm. Approximately $300 \mathrm{~g}$ of substrate $(90 \% \mathrm{CM}: 10 \% \mathrm{CW})$ were fed into the reactors every 24 hours after the same amount of effluent had been discharged. Initially, the organic loading rate was kept at $0.83 \mathrm{gvs} \mathrm{L}^{-1} \mathrm{~d}^{-1}$. Starting day $64, \mathrm{H}_{2}$ was injected into UR using a stainless-steel Mott sparger with a pore size of 2 $\mu \mathrm{m}$, which was mounted at the bottom of the reactor. The sparger measured $12 \mathrm{~cm}$ in length and had a $12 \mathrm{~mm}$ outer diameter. The flow rate of $\mathrm{H}_{2}$ was initially set to $3 \mathrm{~mL} \mathrm{~min}-1\left(\mathrm{H}_{2}: \mathrm{CO}_{2}\right.$ ratio $\left.=2: 1\right)$. To increase the contact time between anaerobic microbes and $\mathrm{H}_{2}$, gas recirculation was introduced from day 64 . $A$ peristaltic pump was used to recirculate the output gas at gas recirculation rates of $7.63 \mathrm{~mL} \mathrm{~min}^{-1}$.

\section{Experimental parameters}

Stirring speed ( 80 vs 120 rpm), CM:CW ratio (90\%:10\% vs. $80 \%: 20 \%$ ), feeding frequency ( $24 \mathrm{~h}$ vs. $48 \mathrm{~h}$ ), and $\mathrm{H}_{2}: \mathrm{CO}_{2}$ ratio (2:1 vs. $\left.4: 1\right)$ were varied from day 79 to 172 to examine how these factors influenced the process performance of the two reactors. The experiment was divided into 6 different phases ( $\mathrm{I}-\mathrm{VI})$ and Table 2 provides an overview of the corresponding parameter-settings.

\section{Hybrid BM setup.}

A hybrid BM set-up where the in-situ reactor (UR) was combined with ex-situ reactor (HR) was tested at the end of the experiment (day 173 to 203 ). The CR was not included in this experiment. The ex-situ upgrading reactor was established using a $2 \mathrm{~L}$ bottle filled with $800 \mathrm{~mL}$ filtered and degassed inoculum (digestate from UR) and $108 \mathrm{~g}$ polyethylene packing materials (Hel-X biocarriers, HXF13KLL+, Christian Stöhr GmbH \& Co). Once a week, $50 \mathrm{~mL}$ of the filtered and pasteurized CM was added to HR (nutrient supply) after the same amount of effluent had been discharged. A peristaltic pump was used to transfer the outlet biogas from the UR to the $2 \mathrm{~L}$ bottle and inject it at the bottom via a diffuser. Figure $1 \mathrm{a} \& 1 \mathrm{~b}$ depicts the in-situ and hybrid configurations.

\section{Sample analysis}

Gas chromatography (GC) (SRI 8160C) with a Flame lonization Detector and $\mathrm{N}_{2}$ as the carrier gas was used to measure the gas composition ( $\mathrm{CH}_{4}$, $\mathrm{CO}_{2}$, and $\mathrm{H}_{2}$ ). A standard biogas mixture $\left(64 \% \mathrm{CH}_{4}\right.$ and $36 \% \mathrm{CO}_{2}$ ) and a $10 \% \mathrm{H}_{2}$ gas mixture (with $90 \% \mathrm{~N}_{2}$ ) (AGA Norway) were used for GC calibration on a regular basis. A digital pH meter (Thermo Scientific Orion Dual Star, USA) was used to measure pH of the digestate. pH measurement was performed immediately after the digestate was discharged from the reactors to avoid $\mathrm{CO}_{2}$ removal from liquid phase.

Digestates from the reactors were collected regularly for total solid (TS), volatile solid (VS), TAN and VFA analysis. TS, VS and TAN were measured according to the Standard Methods for Examination of Water and Wastewater (APHA, 2005). VFA samples were prepared following [22]. VFA concentration was determined using a high performance liquid chromatography (Dionex, Sunnyvale, CA, USA) with Aminex column as described previously [22].

\section{Microbial analysis}

\section{DNA sampling and extraction}

The liquid effluent from each reactor was collected regularly and stored at $-80^{\circ} \mathrm{C}$ until DNA analysis. DNA extraction and sequencing were performed by DNASense (Aalborg, Denmark). The template DNA was extracted using the FastDNA Spin kit for Soil (MP Biomedicals, USA). The DNA extraction was performed following the manufacturer protocol except that samples were subjected to bead beating at $6 \mathrm{~m} / \mathrm{s}$ for $4 \times 40 \mathrm{~s}$ [43]. DNA quantity and quality were assessed using gel electrophoresis with Tapestation 2200 and Genomic DNA screentapes (Agilent, USA). The Qubit dsDNA HS/BR Assay kit was used to determine the concentration of DNA (Thermo Fisher Scientific, USA).

\section{Sequencing analysis}

Microbial community profiles were determined using 16S rRNA gene variable region V4 with primers [515FB] GTGYCAGCMGCCGCGGTAA and [806RB] GGACTACNVGGGTWTCTAAT [44]. The $25 \mu \mathrm{L}$ PCR reactions contained (12.5 $\mathrm{L}$ ) PCRBIO Ultra mix, $400 \mathrm{nM}$ primers and up to $10 \mathrm{ng}$ of extracted DNA. The PCR thermal cycling consisted of a hot start step at $95^{\circ} \mathrm{C}$ for 2 min, followed by 30 cycles of $95^{\circ} \mathrm{C}$ for $15 \mathrm{~s}, 55^{\circ} \mathrm{C}$ for $15 \mathrm{~s}, 72^{\circ} \mathrm{C}$ for $50 \mathrm{~s}$, and then a final $72^{\circ} \mathrm{C}$ extension step for $5 \mathrm{~min}$. For each sample, duplicate PCR reactions were performed, and the duplicates were pooled following PCR. The obtained amplicon libraries were purified using the standard protocol for CleanPCR SPRI beads (CleanNA, NL) with a bead to sample ratio of 4:5. The DNA concentration was quantified using Qubit dsDNA HS Assay kit (Thermo Fisher Scientific, USA) and the quality was confirmed by gel electrophoresis using Tapestation 2200 and D1000/High sensitivity D1000 screentapes (Agilent, USA). The purified libraries were pooled in equimolar concentrations and spiked with > $10 \%$ PhiX control. The denatured library was sequenced on a MiSeq (Illumina, USA) using the Miseq Reagent kit V3.

\section{Bioinformatics}

The sequenced amplicon libraries were trimmed for quality using trimmomatic v. 0.32 and merged [45,46]. The reads were dereplicated and formatted for in the UPARSE workflow [47].Taxonomy was assigned using the RDP classifier as implemented in the script in QIIME and the SILVA database [48-50]. Bioinformatic processing was conducted by RStudio IDE (1.2.1335) (version 4.0.2) [43,51,52]. 


\section{Abbreviations}

$\mathrm{AA}$, acetic acid; $\mathrm{BM}$, biological methanation; $\mathrm{CM}$, cow manure; $\mathrm{CR}$, control reactor; CSTR, continuous stirred tank reactor; CW, cheese waste; GC, gas chromatography; HR, ex-situ upgrading reactor; PA, propionic acid; PtM, Power-to-Methane; TAN, total ammonium nitrogen; TM, thermochemical methanation; TS, total solid; UR, in-situ upgrading reactor; VFA, volatile fatty acids; VS, volatile solid.

\section{Declarations}

\section{Ethics approval and consent to participate}

Not applicable.

\section{Consent for publication}

Not applicable.

\section{Availability of data and material}

The nucleotide sequence dataset used this study is available in the European Nucleotide Archive (ENA).

\section{Competing interests}

The authors declare that they have no competing interests.

\section{Funding}

This work was supported by the Research Council of Norway through grants 270038 (NorBioLab) and 257622 (Bio4Fuels).

\section{Authors' contributions}

RW and SJH conceived the idea for the study. RW set up and operated the reactors, as well as collected samples and process data. RW was responsible for sample analyses and interpretation of the experimental data. RW wrote the first draft of the manuscript, and SJH reviewed and edited subsequent drafts. Both authors read and approved the final manuscript.

\section{Acknowledgements}

The authors wish to thank Michal Sposob and Hege Bergheim for their assistance during the experiments. We thank Sara M. Gaber for providing cheese waste that used as substrate in this study. We also thank Live Heldal Hagen for her assistance in uploading sequences in ENA.

\section{References}

1. Lecker B, Illi L, Lemmer A, Oechsner H. Biological hydrogen methanation-a review. Bioresour Technol. Elsevier; 2017;245:1220-8.

2. Thema M, Bauer F, Sterner M. Power-to-Gas: Electrolysis and methanation status review. Renew Sustain Energy Rev. Elsevier; 2019;112:775-87.

3. Angelidaki I, Treu L, Tsapekos P, Luo G, Campanaro S, Wenzel H, et al. Biogas upgrading and utilization: Current status and perspectives. Biotechnol Adv [Internet]. Elsevier; 2018;36:452-66. Available from: https://doi.org/10.1016/j.biotechadv.2018.01.011

4. Hidalgo D, Martín-Marroquín JM. Power-to-methane, coupling CO2 capture with fuel production: An overview. Renew Sustain Energy Rev. Elsevier; 2020;132:110057.

5. Díaz I, Pérez C, Alfaro N, Fdz-Polanco F. A feasibility study on the bioconversion of $\mathrm{CO} 2$ and $\mathrm{H} 2$ to biomethane by gas sparging through polymeric membranes. Bioresour Technol. Elsevier; 2015;185:246-53.

6. Kougias PG, Treu L, Benavente DP, Boe K, Campanaro S, Angelidaki I. Ex-situ biogas upgrading and enhancement in different reactor systems. Bioresour Technol. Elsevier; 2017;225:429-37.

7. Ghaib K, Ben-Fares F-Z. Power-to-Methane: A state-of-the-art review. Renew Sustain Energy Rev. Elsevier; 2018;81:433-46.

8. Vogt C, Monai M, Kramer GJ, Weckhuysen BM. The renaissance of the Sabatier reaction and its applications on Earth and in space. Nat Catal. Nature Publishing Group; 2019;2:188-97.

9. Alfaro N, Fdz-Polanco M, Fdz-Polanco F, Díaz I. H2 addition through a submerged membrane for in-situ biogas upgrading in the anaerobic digestion of sewage sludge. Bioresour Technol. Elsevier; 2019;280:1-8.

10. Bassani I, Kougias PG, Treu L, Porté H, Campanaro S, Angelidaki I. Optimization of hydrogen dispersion in thermophilic up-flow reactors for ex situ biogas upgrading. Bioresour Technol. Elsevier; 2017;234:310-9.

11. Wahid R, Mulat DG, Gaby JC, Horn SJ. Biotechnology for Biofuels Effects of $\mathrm{H}_{2}: \mathrm{CO}_{2}$ ratio and $\mathrm{H}_{2}$ supply fluctuation on methane content and microbial community composition during in - situ biological biogas upgrading. Biotechnol Biofuels. BioMed Central; 2019;12:104:1-15.

12. Agneessens LM, Ottosen LDM, Voigt NV, Nielsen JL, de Jonge N, Fischer CH, et al. In-situ biogas upgrading with pulse $\mathrm{H}_{2}$ additions: the relevance of methanogen adaption and inorganic carbon level. Bioresour Technol. Elsevier; 2017;233:256-63. 
13. Rachbauer L, Voitl G, Bochmann G, Fuchs W. Biological biogas upgrading capacity of a hydrogenotrophic community in a trickle-bed reactor. Appl Energy. Elsevier; 2016;180:483-90.

14. Porté H, Kougias PG, Alfaro N, Treu L, Campanaro S, Angelidaki I. Process performance and microbial community structure in thermophilic trickling biofilter reactors for biogas upgrading. Sci Total Environ. Elsevier B.V.; 2019;655:529-38.

15. Corbellini V, Kougias PG, Treu L, Bassani I, Malpei F, Angelidaki I. Hybrid biogas upgrading in a two-stage thermophilic reactor. Energy Convers Manag. Elsevier; 2018;168:1-10.

16. Rafrafi Y, Laguillaumie L, Dumas C. Biological Methanation of $\mathrm{H} 2$ and $\mathrm{CO} 2$ with Mixed Cultures: Current Advances, Hurdles and Challenges. Waste and Biomass Valorization. Springer; 2020;1-24.

17. Voelklein MA, Rusmanis D, Murphy JD. Biological methanation: Strategies for in-situ and ex-situ upgrading in anaerobic digestion. Appl Energy. Elsevier; 2019;235:1061-71.

18. Hill DT. A Comprehensive Dynamic Model for Animal Waste Methanogenesis. 1982;1374-80.

19. Angelidaki I, Ahring BK. Thermophilic anaerobic digestion of livestock waste: the effect of ammonia. Appl Microbiol Biotechnol. Springer; 1993;38:560-4.

20. Treu L, Tsapekos P, Peprah M, Campanaro S, Giacomini A, Corich V, et al. Microbial profiling during anaerobic digestion of cheese whey in reactors operated at different conditions. Bioresour Technol. Elsevier; 2019;275:375-85.

21. Luo G, Angelidaki I. Co-digestion of manure and whey for in situ biogas upgrading by the addition of $\mathrm{H} 2$ : process performance and microbial insights. Appl Microbiol Biotechnol. 2013;97:1373-81.

22. Wahid R, Horn SJ. The effect of mixing rate and gas recirculation on biological CO2 methanation in two-stage CSTR systems. Biomass and Bioenergy. Elsevier; 2021;144:105918.

23. Ghanimeh SA, Al-Sanioura DN, Saikaly PE, El-Fadel M. Correlation between system performance and bacterial composition under varied mixing intensity in thermophilic anaerobic digestion of food waste. J Environ Manage. Elsevier; 2018;206:472-81.

24. Comino E, Riggio VA, Rosso M. Biogas production by anaerobic co-digestion of cattle slurry and cheese whey. Bioresour Technol. Elsevier; 2012;114:4653.

25. Piao ZH, Lee J, Kim JY. Effect of substrate feeding frequencies on the methane production and microbial communities of laboratory-scale anaerobic digestion reactors. J Mater Cycles Waste Manag. Springer; 2018;20:147-54.

26. Bassani I, Kougias PG, Treu L, Angelidaki I. Biogas upgrading via hydrogenotrophic methanogenesis in two-stage continuous stirred tank reactors at mesophilic and thermophilic conditions. Environ Sci Technol. ACS Publications; 2015;49:12585-93.

27. Sarker S, Lamb JJ, Hjelme DR, Lien KM. Overview of recent progress towards in-situ biogas upgradation techniques. Fuel. Elsevier; 2018;226:686-97.

28. Martin MR, Fornero JJ, Stark R, Mets L, Angenent LT. A single-culture bioprocess of Methanothermobacter thermautotrophicus to upgrade digester biogas by CO2-to-CH4 conversion with H2. Archaea. Hindawi; 2013;2013.

29. Burkhardt M, Jordan I, Heinrich S, Behrens J, Ziesche A, Busch G. Long term and demand-oriented biocatalytic synthesis of highly concentrated methane in a trickle bed reactor. Appl Energy. Elsevier; 2019;240:818-26.

30. IEA - International Energy Agency. Biological methanation demostration plant in Allendorf, Germany - An upgrading facility for biogass. IEA Bioenergy Task 37 [Internet]. 2018; Available from: https://www.ieabioenergy.com/wp-content/uploads/2018/11/Germany-P2G_Case-Story_LAY2.pdf

31. Moset V, Poulsen M, Wahid R, Højberg O, Møller HB. Mesophilic versus thermophilic anaerobic digestion of cattle manure: Methane productivity and microbial ecology. Microb Biotechnol. 2015;8:787-800.

32. Hagen LH, Frank JA, Zamanzadeh M, Eijsink VGH, Pope PB, Horn SJ, et al. Quantitative metaproteomics highlight the metabolic contributions of uncultured phylotypes in a thermophilic anaerobic digester. Appl Environ Microbiol. Am Soc Microbiol; 2017;83.

33. Hassa J, Maus I, Off S, Pühler A, Scherer P, Klocke M, et al. Metagenome, metatranscriptome, and metaproteome approaches unraveled compositions and functional relationships of microbial communities residing in biogas plants. Appl Microbiol Biotechnol. Springer; 2018;102:5045-63.

34. Luo G, Fotidis IA, Angelidaki I. Comparative analysis of taxonomic, functional, and metabolic patterns of microbiomes from 14 full-scale biogas reactors by metagenomic sequencing and radioisotopic analysis. Biotechnol Biofuels. Springer; 2016;9:1-12.

35. Demirel B, Scherer P. The roles of acetotrophic and hydrogenotrophic methanogens during anaerobic conversion of biomass to methane: a review. Rev Environ Sci Bio/Technology. Springer; 2008;7:173-90.

36. Ahring BK, Westermann P, Mah RA. Hydrogen inhibition of acetate metabolism and kinetics of hydrogen consumption by Methanosarcina thermophila TM-1. Arch Microbiol. Springer; 1991;157:38-42.

37. Gagliano MC, Braguglia CM, Gianico A, Mininni G, Nakamura K, Rossetti S. Thermophilic anaerobic digestion of thermal pretreated sludge: role of microbial community structure and correlation with process performances. water Res. Elsevier; 2015;68:498-509.

38. Treu L, Kougias PG, de Diego-Díaz B, Campanaro S, Bassani I, Fernández-Rodríguez J, et al. Two-year microbial adaptation during hydrogen-mediated biogas upgrading process in a serial reactor configuration. Bioresour Technol. Elsevier; 2018;264:140-7.

39. Reeve JN, Morgan RM, Nölling J. Environmental and molecular regulation of methanogenesis. Water Sci Technol. Elsevier; 1997;36:1-6.

40. Treu L, Campanaro S, Kougias PG, Sartori C, Bassani I, Angelidaki I. Hydrogen-fueled microbial pathways in biogas upgrading systems revealed by genome-centric metagenomics. Front Microbiol. Frontiers; 2018;9:1079.

41. Huber DH, Chavarria-Palma JE, Espinosa-Solares T. Co-digestion of Dairy Cattle Waste in a Pilot-Scale Thermophilic Digester Adapted to Poultry Litter Feedstock: Stress, Recovery, and Microbiome Response. BioEnergy Res. Springer; 2021;1-11. 
42. Gaber SM, Johansen A-G, Devold TG, Rukke E-O, Skeie SB. Manufacture and characterization of acid-coagulated fresh cheese made from casein concentrates obtained by acid diafiltration. J Dairy Sci. Elsevier; 2021;

43. Albertsen M, Karst SM, Ziegler AS, Kirkegaard RH, Nielsen PH. Back to basics-the influence of DNA extraction and primer choice on phylogenetic analysis of activated sludge communities. PLoS One. Public Library of Science San Francisco, CA USA; 2015;10:e0132783.

44. Apprill A, McNally S, Parsons R, Weber L. Minor revision to V4 region SSU rRNA 806R gene primer greatly increases detection of SAR11 bacterioplankton. Aquat Microb Ecol. 2015;75:129-37.

45. Bolger AM, Lohse M, Usadel B. Trimmomatic: a flexible trimmer for Illumina sequence data. Bioinformatics. Oxford University Press; 2014;30:2114-20.

46. Magoč T, Salzberg SL. FLASH: fast length adjustment of short reads to improve genome assemblies. Bioinformatics. Oxford University Press; 2011;27:2957-63.

47. Edgar RC. UPARSE: highly accurate OTU sequences from microbial amplicon reads. Nat Methods. Nature Publishing Group; 2013;10:996-8.

48. Caporaso JG, Kuczynski J, Stombaugh J, Bittinger K, Bushman FD, Costello EK, et al. QIIME allows analysis of high-throughput community sequencing data. Nat Methods. Nature Publishing Group; 2010;7:335-6.

49. Quast C, Pruesse E, Yilmaz P, Gerken J, Schweer T, Yarza P, et al. The SILVA ribosomal RNA gene database project: improved data processing and webbased tools. Nucleic Acids Res. Oxford University Press; 2012;41:D590-6.

50. Wang Q, Garrity GM, Tiedje JM, Cole JR. Naive Bayesian classifier for rapid assignment of rRNA sequences into the new bacterial taxonomy. Appl Environ Microbiol. Am Soc Microbiol; 2007;73:5261-7.

51. Chao A, Gotelli NJ, Hsieh TC, Sander EL, Ma KH, Colwell RK, et al. Rarefaction and extrapolation with Hill numbers: a framework for sampling and estimation in species diversity studies. Ecol Monogr. Wiley Online Library; 2014;84:45-67.

52. Hsieh TC, Ma KH, Chao A. iNEXT: an R package for rarefaction and extrapolation of species diversity (H ill numbers). Methods Ecol Evol. Wiley Online Library; 2016;7:1451-6.

\section{Tables}

\section{Table 1}

Characteristics of inoculum and substrates

\begin{tabular}{|llllll|}
\hline & TS $(\%)$ & VS $(\%)$ & $\mathrm{pH}$ & TAN $\left(\mathrm{g} \mathrm{L}^{-1}\right)$ & TVFA (mM) \\
\hline Inoculum & 3.04 & 1.22 & 8.07 & 1.54 & 4.29 \\
\hline Cow manure & 9.35 & 1.69 & 7.34 & 1.08 & 48.39 \\
\hline Cheese waste & 12.64 & 0.99 & 4.78 & 0.14 & 11.01 \\
\hline
\end{tabular}

TS - Total solid, VS - volatile solid, TAN - total ammonium nitrogen, TVFA - total volatile fatty acids

\section{Table 2}

Operating conditions of control- and in-situ upgrading reactors at different experimental phases

\begin{tabular}{|c|c|c|c|c|c|c|c|c|c|c|c|c|c|}
\hline \multirow[t]{3}{*}{ Parameters } & \multirow[t]{3}{*}{ Unit } & \multicolumn{12}{|c|}{ Phases } \\
\hline & & \multicolumn{2}{|c|}{$\begin{array}{l}\text { I } \\
\text { (day 1-64) }\end{array}$} & \multicolumn{2}{|c|}{$\begin{array}{l}\text { II } \\
\text { (day 65-78 }\end{array}$} & \multicolumn{2}{|c|}{$\begin{array}{l}\text { III } \\
\text { (day 79-85) }\end{array}$} & \multicolumn{2}{|c|}{$\begin{array}{l}\text { IV } \\
\text { (day 93-113) }\end{array}$} & \multicolumn{2}{|c|}{$\begin{array}{l}\text { V } \\
\text { (day 114-140) }\end{array}$} & \multicolumn{2}{|c|}{$\begin{array}{l}\text { VI } \\
\text { (day 141-172) }\end{array}$} \\
\hline & & $\mathrm{CR}$ & UR & $\mathrm{CR}$ & UR & $\mathrm{CR}$ & UR & $\mathrm{CR}$ & UR & $\mathrm{CR}$ & UR & $\mathrm{CR}$ & UR \\
\hline Stirring speed & $\mathrm{rpm}$ & 80 & 80 & 80 & 80 & 140 & 140 & 80 & 80 & 80 & 80 & 80 & 80 \\
\hline CM:CW ratio & $\%$ & 10 & 10 & 10 & 10 & 10 & 10 & 20 & 20 & 10 & 10 & 10 & 10 \\
\hline Feeding frequency & hours & 24 & 24 & 24 & 24 & 24 & 24 & 24 & 24 & 48 & 48 & 24 & 24 \\
\hline $\mathrm{H}_{2}: \mathrm{CO}_{2}$ ratio & - & - & - & - & 2 & - & 2 & - & 2 & - & 2 & - & 4 \\
\hline
\end{tabular}

$\mathrm{CR}$ - control reactor, UR - in-situ upgrading reactor

$\mathrm{CM}$ - cow manure, $\mathrm{CW}$ - cheese waste

Day 86-92 - same conditions as phase II 
Performance data for control and upgrading reactors at different experimental phases (mean \pm S.D)

\begin{tabular}{|c|c|c|c|c|c|c|c|c|c|}
\hline Phases & I & & II & & III & & IV & & V \\
\hline Reactor & CR & UR & CR & UR & CR & UR & CR & UR & CR \\
\hline $\begin{array}{l}\text { Biogas yield } \\
\left(\mathrm{mL} \mathrm{g}^{-1} \mathrm{vs}\right)\end{array}$ & $244.72 \pm 8.29$ & $241.15 \pm 11.01$ & $245.59 \pm 4.52$ & $298.11 \pm 4.84$ & $232.47 \pm 4.16$ & $218.43 \pm 9.70$ & $263.18 \pm 7.16$ & $349.90 \pm 3.81$ & $231.00 \pm 4$ \\
\hline $\begin{array}{l}\mathrm{CH}_{4} \text { yield } \\
\left(\mathrm{mL} \mathrm{g}^{-1} \mathrm{vs}\right)\end{array}$ & $144.77 \pm 2.38$ & $143.50 \pm 3.95$ & $146.34 \pm 2.25$ & $185.44 \pm 1.94$ & $133.52 \pm 2.22$ & $132.96 \pm 5.20$ & $142.19 \pm 1.83$ & $204.15 \pm 1.48$ & $141.70 \pm 6$ \\
\hline \multicolumn{10}{|l|}{$\begin{array}{l}\text { Gas } \\
\text { compositions } \\
(\%)\end{array}$} \\
\hline $\mathrm{CH}_{4}$ & $58.24 \pm 1.09$ & $59.14 \pm 1.25$ & $59.88 \pm 0.66$ & $39.97 \pm 0.60$ & $57.57 \pm 0.13$ & $40.76 \pm 0.45$ & $53.70 \pm 0.36$ & $38.69 \pm 0.38$ & $58.55 \pm 0.5$ \\
\hline $\mathrm{CO}_{2}$ & $41.76 \pm 1.09$ & $40.86 \pm 1.25$ & $40.41 \pm 0.68$ & $28.59 \pm 0.59$ & $42.43 \pm 0.13$ & $26.19 \pm 0.14$ & $46.30 \pm 0.36$ & $28.04 \pm 0.44$ & $41.45 \pm 0.5$ \\
\hline $\mathrm{H}_{2}$ & - & - & - & $31.44 \pm 0.15$ & - & $33.05 \pm 0.31$ & - & $33.27 \pm 0.11$ & - \\
\hline $\begin{array}{l}\mathrm{H}_{2} \\
\text { consumption } \\
(\%)\end{array}$ & - & - & - & $24.96 \pm 0.09$ & - & $45.99 \pm 0.36$ & - & $17.35 \pm 0.70$ & - \\
\hline $\mathrm{pH}$ & $7.92 \pm 0.02$ & $7.94 \pm 0.01$ & $7.94 \pm 0.01$ & $8.10 \pm 0.01$ & $8.15 \pm 0.07$ & $8.28 \pm 0.03$ & $7.91 \pm 0.03$ & $8.11 \pm 0.03$ & $7.82 \pm 0.0 \epsilon$ \\
\hline $\begin{array}{l}\text { TVFA } \\
(\mathrm{mM})\end{array}$ & $18.99 \pm 5.33$ & $17.12 \pm 5.37$ & $30.73 \pm 3.68$ & $44.55 \pm 0.36$ & $30.56 \pm 0.45$ & $66.63 \pm 9.85$ & $37.67 \pm 2.29$ & $62.18 \pm 7.42$ & $40.18 \pm 5 . c$ \\
\hline $\begin{array}{l}\text { AA } \\
(\mathrm{mM})\end{array}$ & $12.04 \pm 4.02$ & $12.07 \pm 4.71$ & $20.58 \pm 1.91$ & 35.68 & $18.32 \pm 1.68$ & $53.50 \pm 9.05$ & $20.57 \pm 2.97$ & $45.83 \pm 9.10$ & $25.59 \pm 3 . \epsilon$ \\
\hline $\begin{array}{l}\mathrm{PA} \\
(\mathrm{mM})\end{array}$ & $6.95 \pm 1.31$ & $5.05 \pm 0.66$ & $10.15 \pm 1.77$ & $8.87 \pm 0.36$ & $12.24 \pm 1.23$ & $13.13 \pm 0.95$ & $17.10 \pm 0.67$ & $16.36 \pm 1.67$ & $14.58 \pm 1.5$ \\
\hline $\begin{array}{l}\text { TAN } \\
\left(\mathrm{g} \mathrm{L}^{-1}\right)\end{array}$ & $2.48 \pm 0.06$ & $2.52 \pm 0.02$ & $2.57 \pm 0.01$ & $2.77 \pm 0.16$ & $3.32 \pm 0.22$ & $2.88 \pm 0.14$ & $3.12 \pm 0.11$ & $3.17 \pm 0.03$ & $2.80 \pm 0.15$ \\
\hline
\end{tabular}

$\mathrm{CR}$ - control reactor, UR - in-situ upgrading reactor

TVFA - total volatile fatty acid, AA - acetic acid, PA - propionic acid

\section{Table 4}

Performance of hybrid reactor system at different $\mathrm{H}_{2}: \mathrm{CO}_{2}$ ratios (mean \pm S.D)

\begin{tabular}{|c|c|c|c|c|c|c|c|c|c|}
\hline $\begin{array}{l}\mathrm{H}_{2}: \mathrm{CO}_{2} \\
\text { ratio }\end{array}$ & $\mathrm{pH}^{*}$ & $\begin{array}{l}\operatorname{TAN}^{*} \\
\left(\mathrm{~g} \mathrm{~L}^{-}\right. \\
\left.{ }^{1}\right)\end{array}$ & $\begin{array}{l}\mathrm{AA}^{*} \\
(\mathrm{mM})\end{array}$ & $\begin{array}{l}\mathrm{CH}_{4} \text { yield }^{+} \\
\left(\mathrm{mL} \mathrm{gVS}^{-1}\right)\end{array}$ & $\begin{array}{l}\mathrm{H}_{2} \\
\text { consumptions } \\
(\%) \\
(\%)\end{array}$ & $\begin{array}{l}\mathrm{CH}_{4} \text { content }(\text { without } \\
\left.\text { considering } \mathrm{H}_{2}\right)^{+} \\
(\%)\end{array}$ & $\begin{array}{l}\text { Output gas } \\
(\%)\end{array}$ & mpositions $^{+}$ & \\
\hline & & & & & & & $\mathrm{CH}_{4}$ & $\mathrm{CO}_{2}$ & $\mathrm{H}_{2}$ \\
\hline $2: 1$ & 8.07 & 1.09 & 4.12 & $257.27 \pm 4.28$ & $60.23 \pm 0.75$ & $79.89 \pm 1.40$ & $63.20 \pm 1.44$ & $16.10 \pm 1.18$ & $20.70 \pm 0.43$ \\
\hline $4: 1$ & 8.06 & 1.01 & 4.23 & $234.15 \pm 3.70$ & $62.22 \pm 2.63$ & $73.09 \pm 2.22$ & $50.58 \pm 0.93$ & $18.64 \pm 1.75$ & $30.78 \pm 0.83$ \\
\hline
\end{tabular}

TAN - total ammonium nitrogen, AA - acetic acid

* - Parameters measured in ex-situ upgrading reactor (HR)

+ - Data from hybrid system (in-situ (UR) + ex-situ (HR))

\section{Figures}




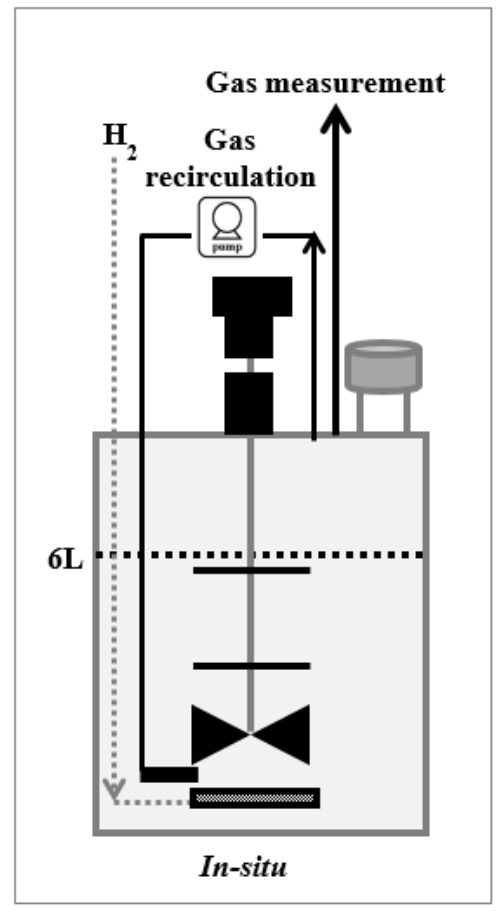

(a)

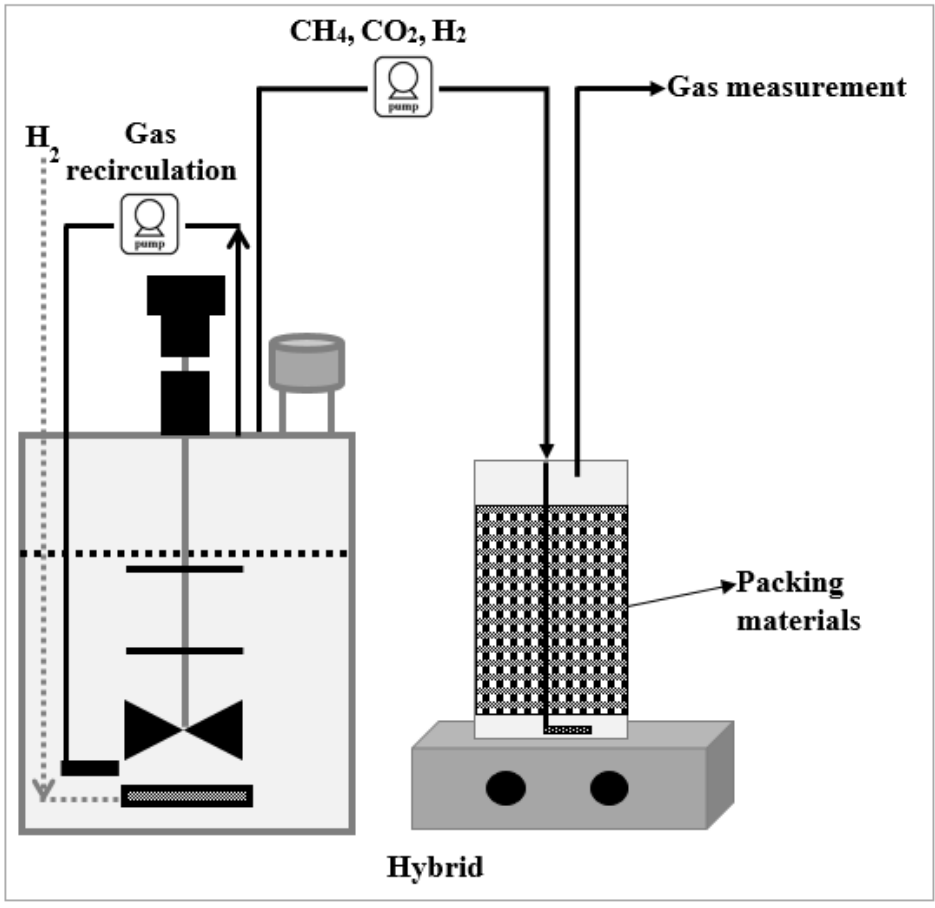

(b)

Figure 1

(a) Illustration of in-situ and (b) hybrid reactor setups

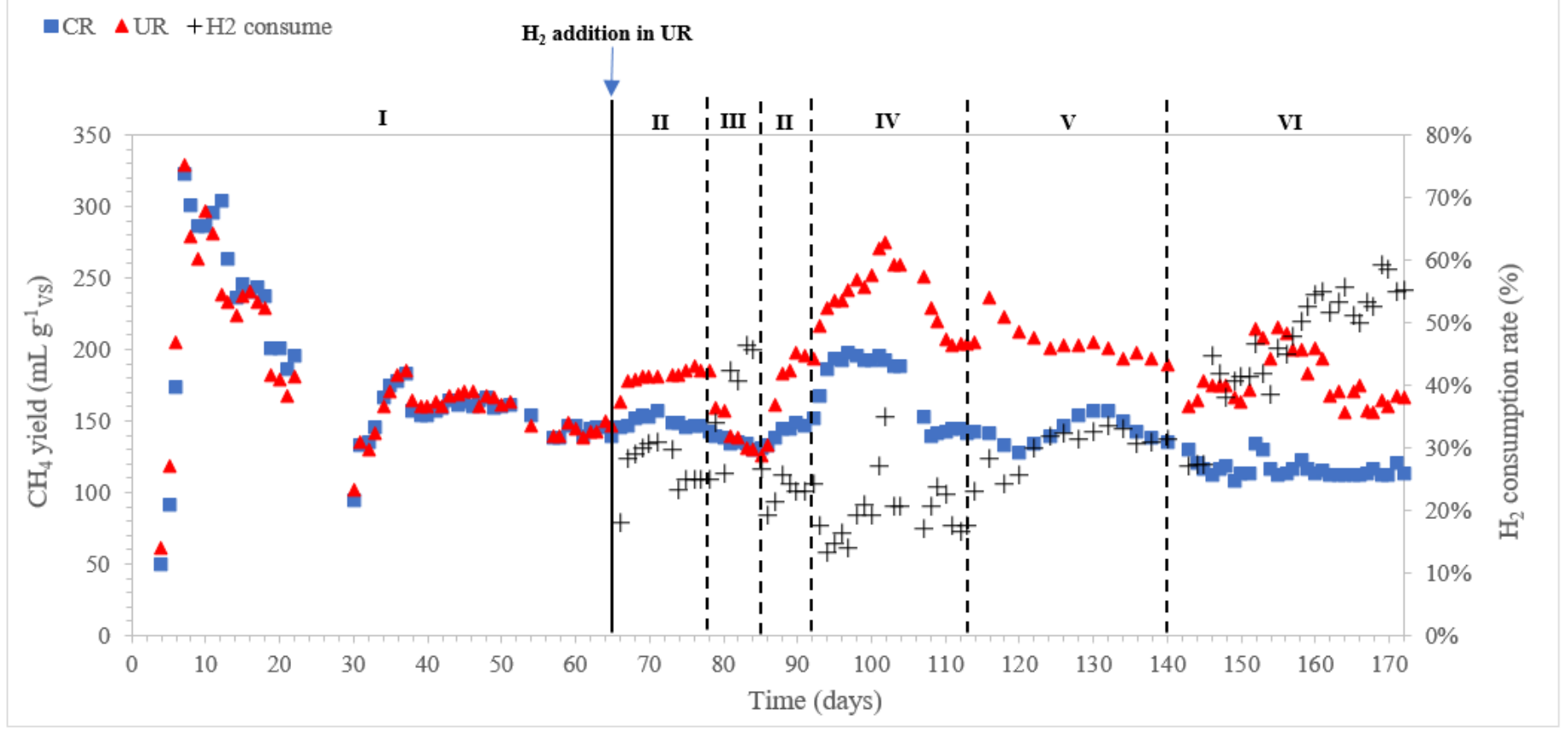

Figure 2

Methane yield and $\mathrm{H} 2$ consumption at different experimental phases ( $\mathrm{I}-\mathrm{VI})$. CR, control reactor; UR, in-situ upgrading reactor; $\mathrm{H} 2$ consumed, $\mathrm{H} 2$ consumption. 


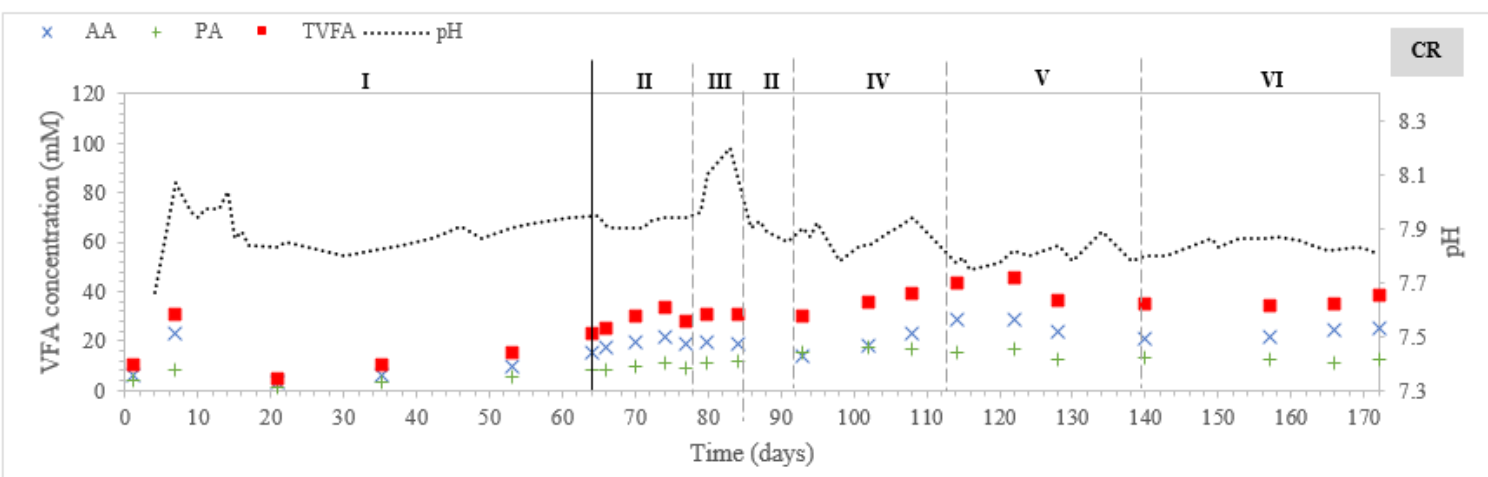

(a)

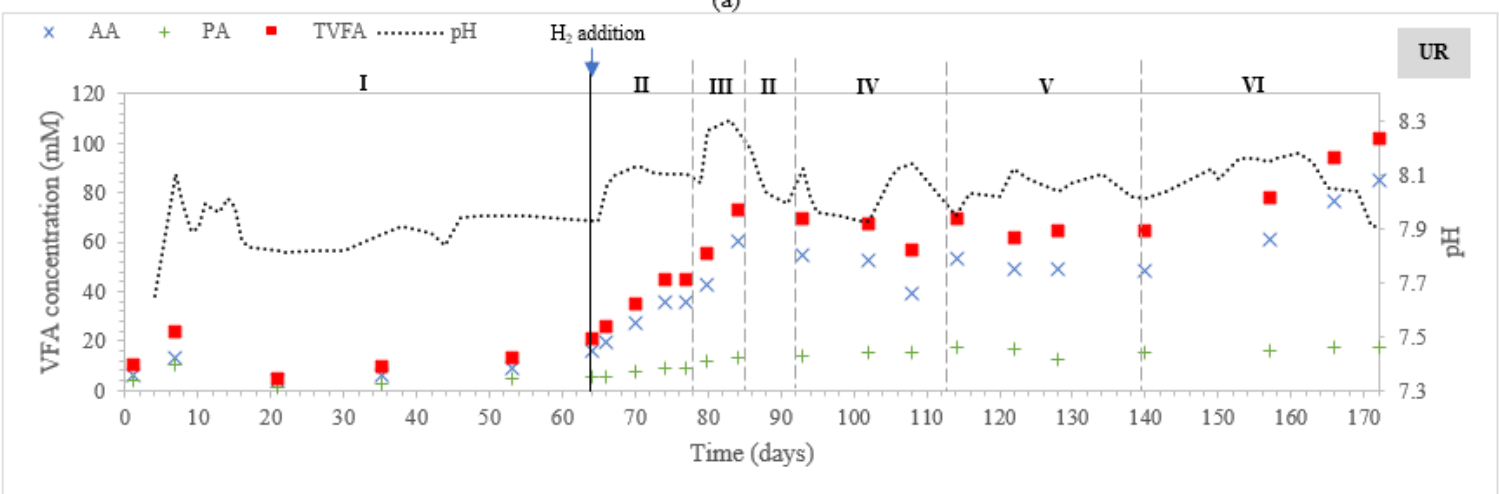

(b)

\section{Figure 3}

$\mathrm{pH}$ and volatile fatty acid concentrations in (a) control reactor (CR) and (b) in-situ upgrading reactor (UR). AA, acetic acid; PA, propionic acid; TVFA, total volatile fatty acids.

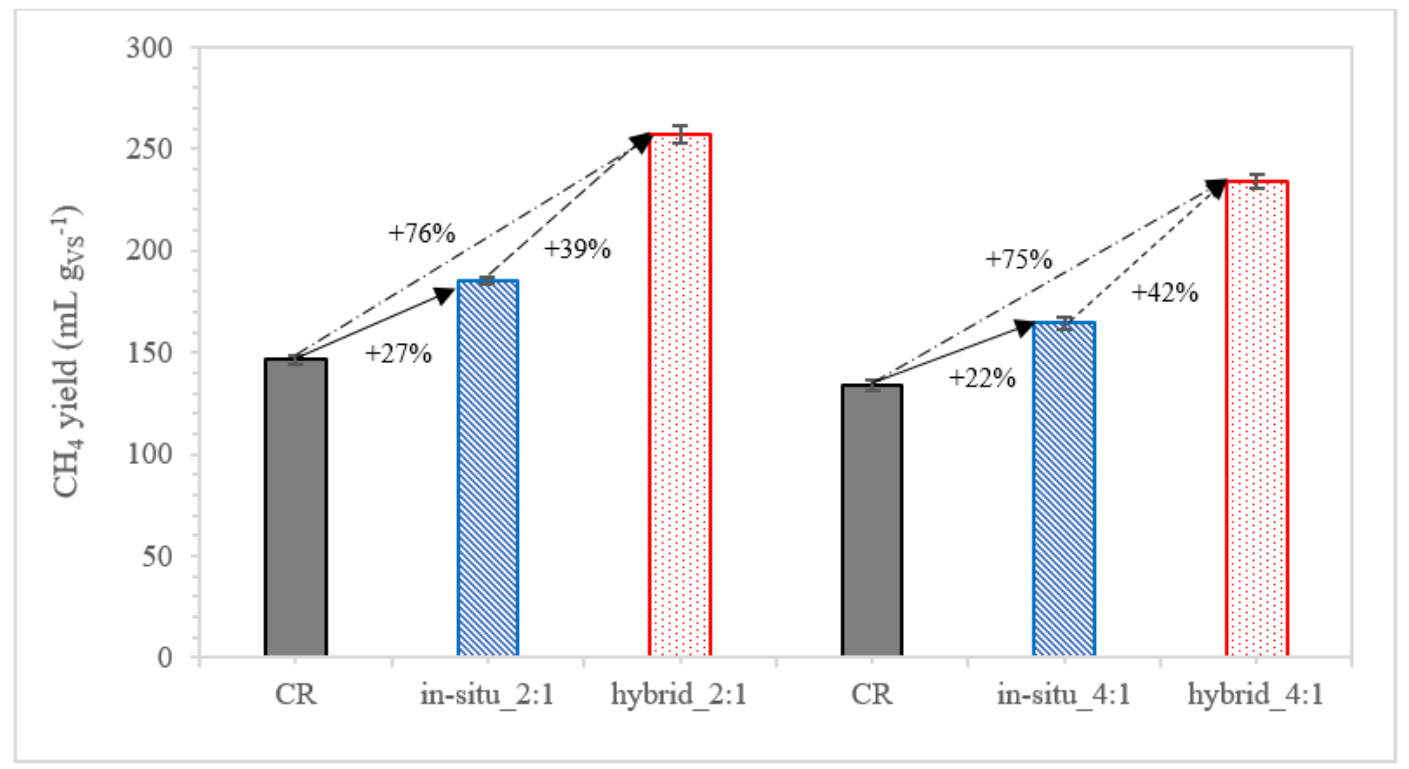

Figure 4

Average methane yield of control reactor (CR), in-situ upgrading reactor (UR) and hybrid upgrading reactor (HR). 2:1 - $\mathrm{H} 2: \mathrm{CO} 2$ ratio of 2:1, 4:1 - $\mathrm{H} 2: \mathrm{CO} 2$ ratio of $4: 1$ 


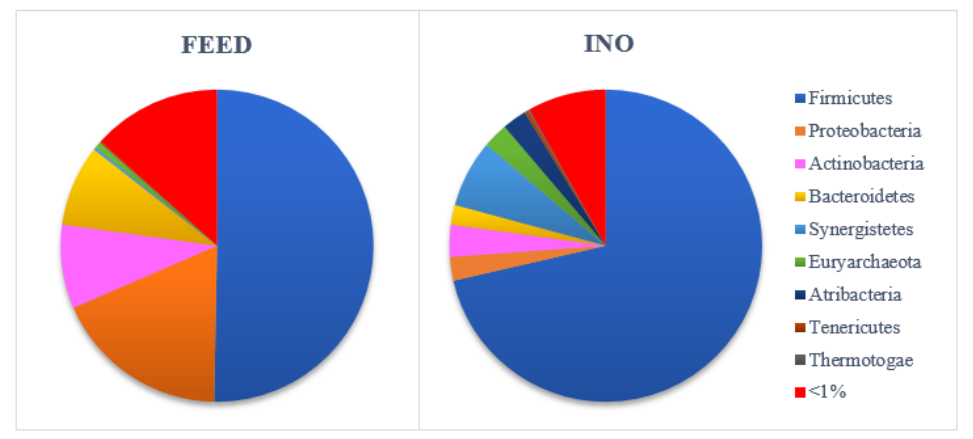

(a)

(b)

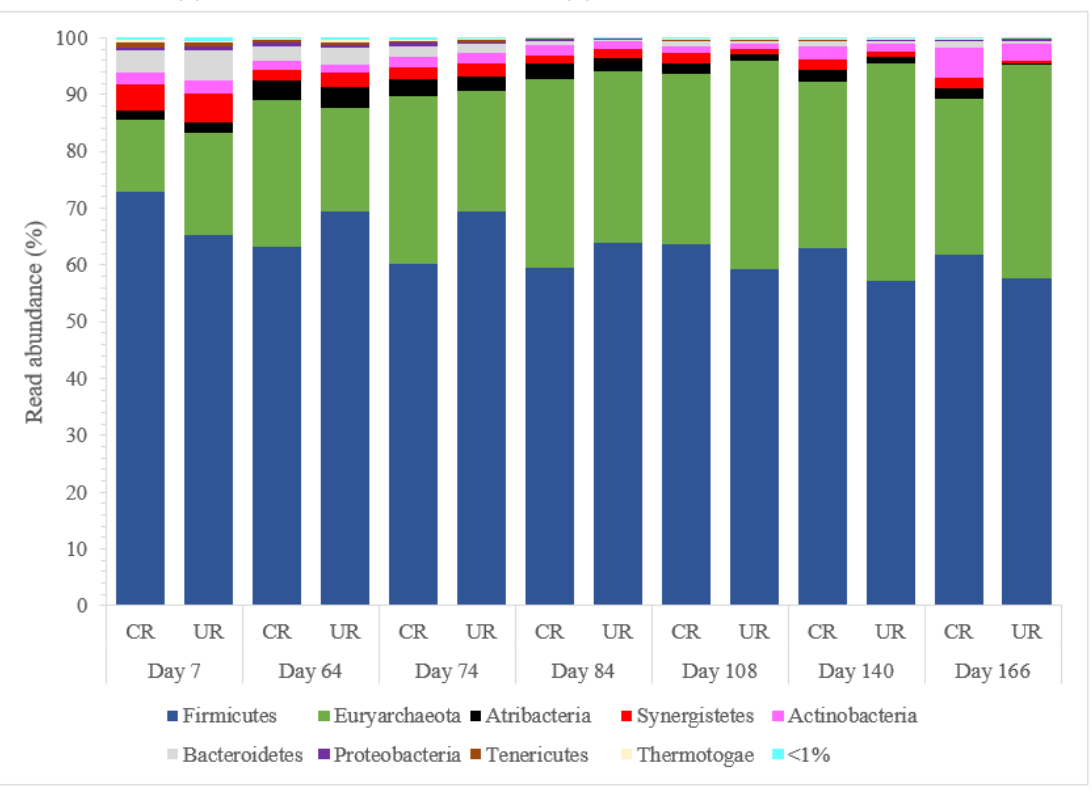

(c)

\section{Figure 5}

Stacked bar plot of the read abundance (\%) of phyla detected in (a) feed, (b) inoculum and (c) control reactor (CR) and in-situ upgrading reactor (UR) over time. Phyla are indicated by the colors displayed in the legend of the figure. Samples with less than 1000 sequences were omitted from the figure. FEED is the biogas substrate used in the study $(90 \% \mathrm{CM}: 10 \% \mathrm{CW})$ and INO indicates the inoculum. 


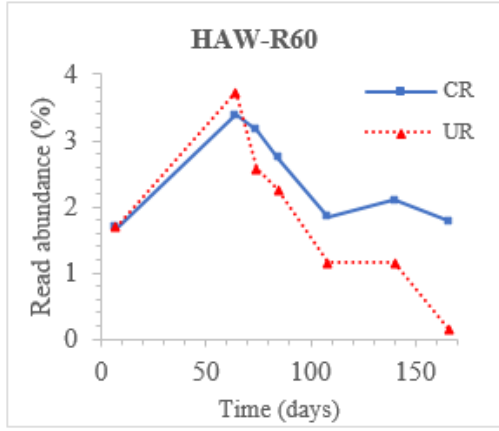

(a)

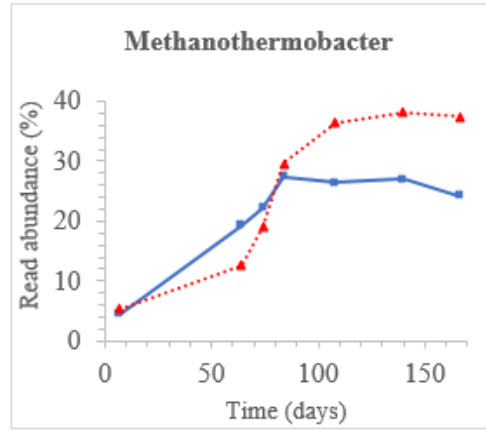

(d)

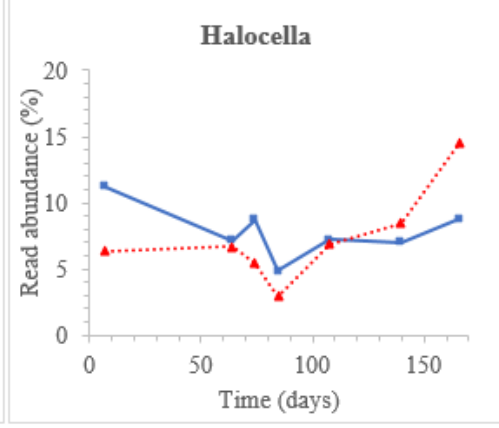

(b)

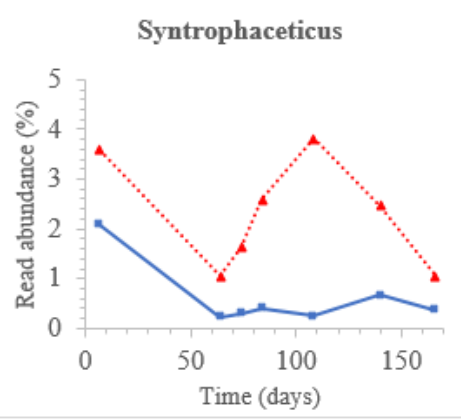

(e)

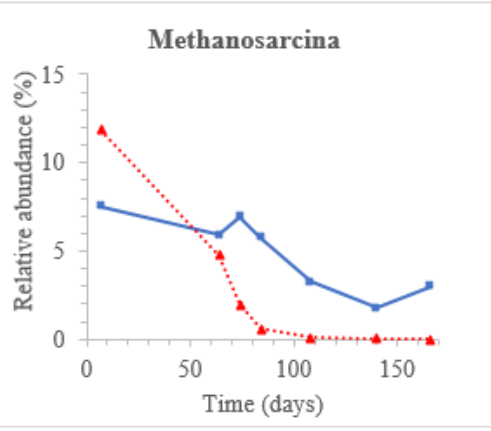

(c)

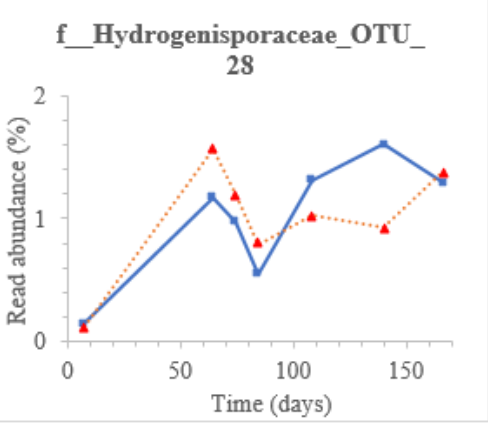

(f)

\section{Figure 6}

Genus abundance (\%) of (a) HAW-R60, (b) Halocella, (c) Methanosarcina, (d) Methanothermobacter, (e) Syntrophaceticus, and (f)

f_Hydrogenisporaceae_OTU_28 in the control and in-situ upgrading reactors over time. Samples with less than 1000 sequences were omitted from the figure. $\mathrm{CR}$, control reactor; UR, in-situ upgrading reactor. 